\title{
Analisis Peran Koperasi Pegawai Negeri (KPN) Syariah Kasabua Ade dalam Meningkatkan Kesejahteraan Ekonomi Anggota
}

\author{
Muhammad Rasyad Al Fajar ${ }^{1^{*}}$, Juraidah ${ }^{2}$ \\ 1,2) Institut Agama Islam Muhammadiyah Bima \\ *Corresponding Author: rasyad1010@gmail.com
}

\begin{abstract}
ABSTRAK - Penelitian ini adalah penelitian kualitatif dengan pendekatan deskriptif. Dalam hal ini peneliti mendeskripsikan Peran Koperasi Pegawai Negeri (KPN) Kasabua Ade dalam meningkatkan Kesejahteraan Ekonomi Anggota. Peneliti melakukan observasi, dokumentasi, dan wawancara dalam mengumpulkan data. Peneliti melakukan pengecekan ulang terhadap data yang diperoleh dan menggunakan teknik triangulasi, dengan tujuan untuk mendapatkan kevalidan data. Setelah itu, menganalisisnya melalui reduksi data, penyajian data dan penarikan kesimpulan. Hasil penelitian ini dapat diketahui bahwa Koperasi Pegawai Negeri (KPN) Kasabua Ade ini memberikan peranan yang sangat besar dalam mensejahterakan anggotanya. Bentuk kesejahteraannya yaitu memberikan kemudahan pelayanan, membantu membiayai pendidikan anak, jaminan kesehatan, dan adanya pelatihan-pelatihan/workshop agar kemampuan Sumber Daya Manusia (SDM) meningkat.
\end{abstract}

Kata Kunci - Meningkatkan; kesejahteraan; Anggota Koperasi

\begin{abstract}
This research is a qualitative research with a descriptive approach. In this case, the researche describes the role of the Kasabua Ade Civil Service Cooperative (KPN) in improving the economic welfare og members. Therefore the researchers conducted observations, documentation, dan interviews. The researcher recheck the data obtained and user triangulation techniques, with the aim of obtaining the validity of the data. After that, analyze it through data reduction, data presentation and drawing conclusions. From the esults of this study, it can be seen that the Kasabua Ade Civil Service Coomparative (KPN) provides a very large role in the welfare of this members, the form of welfare is to provided, help finance children's educatioan, helath insurance, and the existence of workshop tarinings so that resources are provided. Human resources (SDM) increased.
\end{abstract}

Keywords - Perspective Omproved; The Welfare; Of Cooperative Members

\section{PENDAHULUAN}

Perekonomian di Indonesia menganut prinsip kebersamaan, hal tersebut termaksud dalam Pasal 33 Undang-Undang Dasar 1945 ayat 1 yang berbunyi, "Perekonomian disusun sebagai usaha bersama berdasar asas kekeluargaan". Asas inilah yang memberikan dorongan kepada setiap anggota untuk melakukan kerja. Asas ini juga mendasar prinsip dasar dalam koperasi yang dapat dilihat dari terjemahan etimologi koperasi. Koperasi berasal dari bahasa latin, yaitu co yang berarti bersama dan operare berarti bergerak. Kedua kata ini mengandung arti bekerjasama untuk mencapai tujuan.

Jadi secara singkat dalam koperasi harus ditunjukkan kebersamaan dalam menjalankan usaha. Tujuan dari koperasi ini memenuhi kebutuhan anggota dan 
masyarakat sekitarnya melalui unit usaha, salah satunya dengan cara menjual barang keperluan sehari-hari dengan harga murah. Usaha koperasi dijalankan oleh para anggota, tidak boleh ada kecurangan di dalamnya. Karena, setiap anggota koperasi menjalankan fungsi dan peranannya masing-masing. ${ }^{1}$

Menurut undang-undang nomor 12 tahun 1967 tentang pokok-pokok perkoperasian, koperasi Indonesia adalah organisasi ekonomi rakyat berwatak sosial, beranggotakan orang-orang atau badan hukum koperasi yang merupakan tata susunan ekonomi sebagai usaha bersama berdasar asas kekeluargaan. Sedangkan menurut Undang - Undang Nomor 25 Tahun 1992 tentang perkoperasian, menyatakan bahwa koperasi adalah badan usaha yang beranggotakan orang-seorang atau badan hukum koperasi dengan melandaskan kegiatannya berdasarkan prinsip koperasi sekaligus sebagai gerakan ekonomi rakyat yang berdasar atas asas kekeluargaan.

Koperasi adalah perusahaan yang berorientasi pada tercapainya kemandirian pengguna jasa (use oriented firm) bukan perkumpulan modal seperti halnya badan usaha lainnya yang beroreantasi kepada investor (investor oriented firm). Meskipun modal merupakan unsur penting dalam menjalankan usaha, tetapi modal bukan satu-satunya jalan untuk mencapai tujuan koperasi. Jika koperasi menggunakan cara seperti badan usaha lainnya, maka koperasi akan menghadapi pergulatan tanpa akhir (never ending struggle) untuk mencapai tujuannya. Karena bagaimanapun, yang menjadi modal utama koperasi adalah kesediaan anggotannya untuk mengembangkan unit-unit usaha melalui wadah koperasi. $^{2}$

Tujuan koperasi menurut Undang-undang Nomor 25 Tahun 1992, bertujuan memajukan kesejahteraan anggota pada khususnya dan pada masyarakat pada umumnya serta ikut membangun tatanan perekonomian nasional dalam rangka mewujudkan masyarakat yang maju, adil, makmur dan berdasarkan Pancasila dan Undang -Undang Dasar 1945.3

Koperasi Pegawai Negeri (KPN) Kasabua Ade Kota Bima merupakan salah satu koperasi yang anggotanya adalah para Pegawai Negeri Sipil dari berbagai dinas yang ada di Kota Bima. Koperasi Pegawai Negeri (KPN) Kasabua Ade Kota Bima adalah salah satu koperasi dimana salah satu unit usahanya adalah unit usaha simpan pinjam (USP), seluruh anggotanya adalah para pegawai negeri sipil yang ada di setiap instansi yang ada di Kota Bima. Koperasi ini berada di bawah naungan KOPERINDAG (Koperasi Perindustrian dan Perdagangan)

\footnotetext{
1 Jumriani Nur, Peran koperasi dalam meningkatkan kesejahteraan anggotanya pada koperasi Masjid AlMarkaz Al-Islam makasar (Skripsi “universitas Islam Negeri Alaudin Makassar 2019), hal 1.

2 Burhanuddin Koperasi syariah dan pengaturan Di Indonesia, Malang (UIN-Maliki Press 2012), hal 1-

2.

${ }^{3}$ Burhanuddin Koperasi syariah dan pengaturan Di Indonesia Malang (UIN-Maliki Press,2012), 11-12.
} 
yang keseluruhan anggotanya adalah Pegawai Negeri Sipil dengan jumlah anggotanya 1.647 orang, yang dimana bunga dari koperasi ini berada pada angka $1.5 \%$ pada awalnya, tapi sekarang sudah turun menjadi $1.2 \%$ dikarenakan sedang berjalan menuju Syariah. Bunga yang turun sampai 1.2\% bertujuan untuk membantu atau meringankan beban dari anggota KPN Kasabua Ade dengan tingkat bunga yang rendah. Anggota tetap yang ada di koperasi Kasabua Ade ini wajib menyetorkan simpanan wajib Rp 60.000 setiap bulan termaksud dengan dana kesehatan Rp10.000 untuk setiap bulannya, berbeda dengan anggota yang baru masuk mereka dikenakan simpanan pokok Rp 25.000 hanya untuk diawalnya saja, seterusnya wajib menyetorkan seperti yang dilakukan anggota tetapnya. Untuk pinjaman anggotanya koperasi hanya mampu memberikan batas pinjaman nilai uangnya hanya sebesar Rp 50.000 .000 saja sesuai batas kemampuan koperasi.

Koperasi Kasabua Ade adalah koperasi yang mengedepankan kesejahteraan anggotanya lewat simpan pinjam yang tidak memberatkan para anggota. Koperasi yang berdiri sejak bulan januari 2002 yang beranggota awalnya yaitu hanya 20 orang. Untuk merintis koperasi ini dikumpulkan dari kepala UPT BAPPEDA, KEHUTANAN, DIKPUT hingga tahun 2019 beranggotakan 1.647 orang. 4

Mengingat pentingnya peranan koperasi disini, jadi penulisan ini bertujuan untuk mengetahui bagaimana peran Koperasi Pegawai Negeri (KPN) Kasabua Ade dalam mensejahteraan ekonomi anggotanya. Oleh karena itu dengan adanya Koperasi Pegawai Negeri Kasabua Ade diharapkan dapat membantu pembangunan sektor ekonomi anggotanya sehingga mereka dapat mendirikan sebuah usaha yang bisa menciptakan lapangan kerja.

Berdasarkan uraian di atas maka penulis tertarik meneliti tentang "Analisis Peran Koperasi Pegawai Negeri (KPN) Syariah Kasabua Ade dalam Meningkatkan Kesejahteraan Ekonomi Anggota."

\section{LANDASAN TEORI}

Koperasi

\section{Pengertian Koperasi}

Koperasi berasal dari bahasa latin coopere atau cooperation dalam bahasa inggris, Co berarti bersama atau operation berati bekerja. Jadi, cooperation berati

${ }^{4}$ Edy Rahman, SE,M.Ak, Bendahara I Koperasi Kasabua Ade Kota Bima, hasil wawancara awal, Tanggal 1 Maret 2021 
bekerjasama. Dalam hal ini, bekerjasama yang dilakukan oleh orang-orang yang mempunyai kepentingan dan tujuan yang sama. ${ }^{5}$

Menurut Masjfuk Zuhdi yang dimaksud dengan Koperasi adalah suatu perkumpulan atau berorganisasi yang berangggotakan orang-orang atau badan hokum yang bekerja sama dengan penuhkesadaran untuk meningkatkan kesejahteraan anggota atas dasar suka rela secra kekeluargaan. ${ }^{6}$

\section{Dasar Hukum Koperasi}

Menurut Undang-Undang Nomor 12 tahun 1967 tentang pokok-pokok perkoperasian, koperasi Indonesia adalah organisasi ekonomi rakyat yang berwatak sosial, beranggotakan orang-orang atau badan hukum koperasi dengan berasaskan kekeluargaan. Sedangkan menurut Undang-Undang Nomor 25 Tahun 1992 tentang perkoperasian, koperasi adalah badan usaha yang beranggotakan orang seorang atau badan hukum dimana kegiatan yang dilakukan berdasarkan prinsip koperasi, sekaligus untuk menggerakan ekonomi rakyat yang berdasarkan atas asas kekeluargaan. ${ }^{7}$

\section{Tujuan dan fungsi Koperasi}

Tujuan utama koperasi adalah meningkatkan kesejahteraan anggota khususnya dan masyarakat pada umumnya. Koperasi Indonesia merupakan perkumpulan orang-orang, bukan perkumpulan modal sehingga laba bukan merupakan ukuran utama kesejahteraan anggota. Meskipun keduanya merupakan satu kesatuan yang tidak dapat dipisahkan, manfaat jasa koperasi adalah lebih utama bagi anggota dari pada laba untuk sendiri. Kesemuanya ini dapat dicapai secara seimbang apabila dalam kegiatannya ada penyatuan unitunit usaha yang disumbangkan oleh masing-masing anggota. ${ }^{8}$

Tugas utama perusahaan koperasi adalah menunjang kegiatan usaha para anggotanya dalam rangka meningkatkan kepentingan perekonomian para anggotanya melalui pengadaan barang dan jasa yang butuhkannya, yang sama sekali tidak tersedia di pasar, atau ditawarkan dengan harga, mutu, atau syaratsyarat yang lebih menguntungkan dari pada yang ditawarkan pada anggota di pasar atau oleh badan-badan resmi. ${ }^{9}$

${ }^{5}$ Bernhard Limbang pengusaha koperasi (Jakarta selatan margaretha pustaka Jl. Agung Raya no. 10 Lenteng Agung), 60.

${ }^{6}$ H. Hendi Suhendi fiqh Muamalah (Depok : Rajawali Press,2019),289.

7 Sahril Akbar, Tinjauan Hukum Islam Mengenai Praktik Koperasi Kpn Kasabua Ade Kota Bima,("Skripsi" IAI Muhammadiyah Kota Bima,2020), 12-13.

8 Triana Sofiani, “Konstruksi Norma Hukum Koperasi Syariah Dalam Kerangka Sistem Hukum Koperasi Nasional", Jurnal Hukum Islam, Vol. 12, No. 1, (Desember, 2014$), 137$.

9 Triana Sofiani, "Konstruksi Norma Hukum Koperasi Syariah Dalam Kerangka Sistem Hukum Koperasi Nasional", Jurnal Hukum Islam, Vol. 12, No. 1, (Desember, 2014), 137. 


\section{Kesejahteraan}

Sejahtera menurut kamus bahasa Indonesia berasal dari kata sejahtera yang mempunyai makna aman, sentosa, makmur, dan selamat, terlepas dari segala macam gangguan, kesukaran dan sebagainya. Kata sejahtera mengandung pengertian dan bahasa sansekerta "catera" yang berarti paying. Dalam konteks sejahtera, "catera" adalah orang yang sejahtera, yakni yang dalam hidupnya bebas dari kemiskinan, kebodohan, ketakutan, atau kekhawatiran sehingga hidupnya aman dan tentram, baik secara lahir maupun batin.

Kesejahteraan masyarakat adalah kondisi terpenuhinya kebutuhan dasar yang tercermin dari rumah yang layak, tercukupinya kebutuhan sandang dan pangan, biaya pendidikan dan kesehatan yang murah dan berkualitas atau kondisi dimana setiap individu mampu memaksimalkan utilitasnya pada tingkat batas anggaran tertentu dan kondisi dimana tercukupinya kebutuhan jasmani dan rohani. ${ }^{10}$ Kesejahteraan merupakan cita-cita utama suatu negara dengan visi pengentasan kemiskinan yang dapat direalisasikan dengan berbagai program penunjang. ${ }^{11}$ Keberadaan koperasi merupakan bagian dari program penunjang tersebut.

\section{Peran Koperasi Dalam Meningkatkan Kesejahteraan Anggota}

Koperasi merupakan salah satu lembaga yang dijadikan pemerintah sebagai bentuk organisasi rakyat yang dapat memajukan kesejahteraan umum. Koperasi dianggap cocok bagi golongan ekonomi bawah untuk meningkatkan taraf hidup ekonominya. Keberhasilan suatu koperasi dilihat dari kesejahteraan anggotanya. Koperasi dapat memberikan kesejahteraan, karena anggota dapat menciptakan nilai tambah dari usaha yang dijalankan. Untuk itu, penting setiap anggota dalam meningkatkan partisipasinya. Anggota koperasi memiliki makna yang sangat penting, selain sebagai pemilik, ia juga merupakan pengguna (konsumen) dalam koperasi. Oleh sebab itu, partisipasi anggota sangatlah dibutuhkan untuk mencpai tujuan dari lembaga ini.

Kesejahteraan anggota dapat diukur dari pendapatan yang diperolehnya, dengan demikian tujuan koperasi untuk meningkatkan kesejahteraan anggota dapat dilihat dari tingkat pendapatan anggota. Pendapatan ini dapat berupa uang atau juga dalam bentuk barang yang mampu dibeli anggota. ${ }^{12}$

10 Dahliana Sukmasari “Konsep kesejahteraan masyarakat dalam pespektif Al - Qur'an”, jounal of Qur'an and Hadis Studies, Vol. 3 No. 1 (juni 2020),16-17.

11 Ismail, Kemiskinan Perspektif Ekonomi Islam, Jurnal Ekonomi Syariah (J-ESA), Volume 3, Nomor $1,2020$.

12 Jumriani Nur peran koperasi dalam meningkatkan kesejahteraan Anggota pada Koperasi Masjid Al markaz Al - Islam Makassar (“Skripsi” Universitas Islam Negeri Alauddin Makassar,2019), 28. 


\section{Penelitian Yang Relevan}

Skripsi Jumriani Nur dengan judul penelitian "Peran Koperasi Dalam meningkatan Kesejahteraan anggota pada Koperasi Masjid Al Markaz Al Islami Makassar". Penelitian menggunakan metode kualitatif dan menggunakan analisis deskriptif kualitatif. Dari hasil peneltian tersebut menujukan bahwa koperasi Al Markaz Al Islam memberikan peran yang sangat besar dalam kehidupan anggota dan upaya peningkatan kesejahteraan anggota dilihat dari pelayanan dan kemudahan yang diberikan, walaupun terdapat permasalahan internal antar anggota, ini masih dapat teratasi oleh koperasi dengan menigkatkan partisipan anggotanya. Dari sisi persamaannya sama-sama meniliti tentang peran koperasi dalam meningkatkan kesejahteraan anggota. Namun sisi perbedaan koperasi Al Markasz Al Islam ini berfokus pada peningkatan kesejahteraan hanya dicapai dengan pelayanan dan kemudahan yang diberikan Koperasi terhadap anggota, namun peneltian melihat dari sisi internal Koperasi dan dampak yang akan ditimbulkan.

Dalam jurnal Muhammad syaiful, Hasan Aedy Dkk, dengan judul Strategi Koperasi Dalam Meningkatkan Kesejahteraan Anggota. Penelitian ini menggunakan metode kualitatif. Dari hasil penelitian tersebut menunjukan untuk meningkatkan kesejahteraan anggota, strategi yang digunakan koperasi tersebut yaitu meningkatkan partisipasi anggota, pelayanan kepada anggota dan juga menambah modal kerja sama dengan menigkatkan simpanan wajib. Dari sisi persamaanya, sama-sama meneliti tentang peran Koperasi dalam meningkatkan kesejahteraan anggota. Namun sisi perbedaannya jurnal ini berfokus pada strategi - strategi yang harus dilakukan dalam peningkatan kesejahteraan anggota, namun penelitian lebih berfokus pada penigkatan kesejahteraan anggota dan apa saja solusi yang ditawarkan dalam meningkatkan kesejahteraan anggota.

Skripsi Rizki Fathia Rahmah Peranan Koperasi Dalam Meningkatkan Kesejahteraan Masyarakat Di Sekitar Pondok Pesantren Roudlatun Qur'an Kota Metro. Penelitian ini menggunakan medote kualitatif dan menggunakan analisis deskriptif. Dari hasil penelitian tersebut menujukan bahwa Koperasi pondok Pesantren Roudatul Qur'an terlaksana dengan baik. Hal ini dilihat dari keefektifan Koperasi dalam peminjaman modal, partisipasi anggota, tingkat pelayanan kepada anggota dan juga usaha yang dijalankan. Dari sisi persamaannya, sama-sama meniliti tentang peranan koperasi dalam

meningkatkan kesejahteraan anggota. Namun sisi perbedaanya Koperasi Raoudllatul Qur'an ini berfokus pada peningkatan kesejahteraan masyarakat di sekitar Pondok Pesantren Roudlatul Qur'an yang dicapai dengan keefektikan koperasi dalam menjalakan koperasinya, sedangkan penelitian ini berfokus pada 
kesejahteraan anggota dicapai dengan peningkatan usaha, kemudahan dalam pinjaman, untuk membangun sebuah usaha.

Dalam jurnal Dahliana Sukmasari dengan judul konsep kesejahteraan masyarakat dalam perspektif Al Qur'an. Penelitian menggunakan metode kualitatif. Dari hasil penelitian tersebut menujukan bahwa koperasi memiliki kesamaan dengan ekonomi Islam, prinsip dasar koperasi adalah kerjasama, gotong royong dan demokrasi ekonomi, menuju kesejahteraan umum. Islam juga menekankan pentingnya kerjasama dan tolong menolong (ta'awun), persaudaran (ukhuwah) dan pandangan hidup demokrasi (musyawarah) sebagaimana dalam QS. Al-Maidah Ayat 2. Kesejahteraan ekonomi ini dilihat dari bagaimana koperasi mampu memberikan peranan yang besar baik dari sisi internal maupun eksternal koperasi. Dari sisi persamaanya, sama-sama meniliti tentang Koperasi Dalam Meningkatkan Kesejahteraan Anggota. Namun dari sisi perbedaannya jurnal ini berfokus pada peningkatan ekonomi masyarakat secara luas, namun penelitian ini melihat kesejahteraan anggota koperasi khususnya.

\section{METODOLOGI PENELITIAN}

Jenis penelitian yang digunakan oleh peneliti adalah kualitatif deskriptif. Menurut Sugiyono, metodologi penelitian kualitatif adalah metodologi peneltian yang digunakan untuk meneliti pada kondisi obyek yang alamiah di mana peneliti adalah sebagai instrumen kunci. ${ }^{13}$ Untuk sumber datanya menggunakan data primer dan sekunder. Adapun pengumpulan datanya dengan Teknik Wawancara, Observasi, dan Dokumentasi.

\section{HASIL PENELITIAN DAN PEMBAHASAN Penyajian Data dan Analisis Data}

Penyajian data merupakan salah satu kegiatan dalam pembuatan laporan hasil peneliti yang telah di lakukan agar data yang telah di kumpulkan dapat di pahami dan analisis sesuai dengan tujuan yang diinginkan. Berdasarkan hasil wawancara dengan Bapak Edy Rahman selaku pemberi pinjaman menyatakan bahwa Peran Koperasi Pegawai Negeri (KPN) Kasabua Ade dalam meningkatkan kesejahteraan ekonomi anggota.

"Pertama, memberikan pembiyaan dalam bentuk mudharabah dan ijarah untuk kegiatan usaha anggota koperasi. Kedua, dari hasil kegiatan setiap tahun koperasi memberikan SHU dan memberikan bonus pada anggota sesuai dengan tingkat aktivitas belanjanya di koperasi. Ketiga, Koperasi Pegawai Negeri (KPN) Kasabua Ade memberikan fasilitas-fasilitas dana kesehatan, biaya pendidikan anak, dan pelatihan. Dana kesehatan ini khusus pembiyaan sosial dalam bentuk Qardul Hasan untuk pengobatan

13 Ahmad Usman, M. Si, “Mari Belajar Meneliti”, (Jakarta: Granata Press 2009), hal 225 
dalam daerah minimal Rp. 1.000.000, kalau di luar daerah maksimalnya Rp. 2.000.000 untuk yang sosialnya. Secara peningkatan ekonominya sesuai dengan kebutuhan anggota ada produk mudharabah, produk musyarakah sesuai dengan jenis usaha yang dijalankan oleh anggota dan di berikan pembiayaan jumlah nilai pelporannya itu maksimalnya Rp. 60.000.000, jangka waktunya bervariasi adanya 10 bulan dan maksimalnya 3 tahun 5 bulan. Dari pembiayaan-pembiyaan itu baik Qardul Hasan, ijarah, musyarakah, mudharabah adalah sesuai dengan kesepakatan margin secara tertulis." 14

Dari penjelasan bapak Edy Rahman di atas peneliti menyimpulkan bahwa Peran Koperasi Pegawai Negeri (KPN) Kasabua Ade dalam meningkatan kesejahteraan ekonomi anggota adalah dalam bentuk pembiayaan kesehatan, Pendidikan dan pelatihan, dan modal/pembiayaan usaha. Di mana Koperasi memberikan pembiyaan dalam bentuk mudharabah, ijarah, dan Qordul Hasan untuk kegiatan usaha anggota. Sedangkan daa bentuk kesehatan seperti fasilitasfasilitas dana kesehatan baik itu di luar daerah maupun di dalam daerah.

Informasi lain diperoleh dari pemaparan ibu Nuningsih. Menurutnya bahwa anggota bisa dapat secara langsung ke Koperasi apabila membutuhkan pinjaman.

“Bahwa anggota bisa pinjam langsung ke Koperasi apabila memerlukan dana mendadak, ini menjadi upaya yang di lakukan oleh koperasi yang dapat dirasakan langsung kepada anggota dalam memberikan kontribusinya bagi kesejahteraan anggota. Kalau di tanya tentang kesejahteraan yang di berikan oleh koperasi ada, terutama kita sebagai anggota biasa disini, bisa pinjam sesuai dengan kebutuhan seperti pembiyaan sekolah anak, kesehatan. Saya pinjam ke koperasi dan mereka tidak menyulitkan, mudah sekali. Ini sangat membantu saya."15

Berdasarkan hasil wawancara dengan ibu Nuningsi selaku anggota di Koperasi Pegawai Negeri (KPN) Kasabua Ade peneliti menyimpulkan bahwa Koperasi Pegawai Negeri (KPN) Kasabua Ade memberikan kemudahan kepada anggota dalam hal pemberian pinjaman, terutama terhadap suatu hal yang mendesak. Inilah yang menjadi salah satu tujuan koperasi, yang mampu hadir memberikan kemudahan kepada anggota yang pada akhirnya akan tercipta kesejahteraan bagi anggota. Pinjaman yang diberikan Koperasi kepada anggota maksimal Rp 5.000.000, pemberian pinjaman tidak serta merta diberikan secara langsung kepada anggota, tetapi harus melalui tahapan. Alasanya untuk menghindari pinjaman bermasalah yang disebabkan oleh ketidakmampuan anggota membayar.

14 Edy Rahman,Wawancara 23 Oktober 2021

${ }^{15}$ Nuningsih, Wawancara 23 Oktober 2021 
Pemaparan dari ibu St. Rahmawati menjelaskan bahwa:

"Peran koperasi Alhamdulilah dek, semenjak bergabung pada Koperasi Pegawai Negeri (KPN) Kasabua Ade ini, saya bisa membeli sedikit-sedikit kebutuhan rumah tangga, walaupun SHU yang di terima tidak banyak tapi ini dapat membantulah dalam menambah pemasukan. Kalau ditanya kesejahteraan yang diberikan oleh Koperasi Pegawai Negeri (KPN) Kasabua Ade ini alhmdulilah sejahtera dan sangat membantu banget ketika kita pinjam di koperasi tersebut dan di sana juga cara pelayanan cepat, mudah sekali dan tidak menyulitkan, ini sangat membantu saya."16

Hasil wawancara dengan ibu St Rahmawati, peneliti menyimpulkan bahwa Koperasi Pegawai Negeri (KPN) Kasabua Ade bagi anggota itu memberikan peranan, termasuk kepada anggota yang memperoleh SHU dari Koperasi. Anggota Koperasi Pegawai Negeri (KPN) Kasabua Ade pada umumnya memiliki pekerjaan juga sehingga bergabung pada Koperasi ini membantu menambah pemasukan. Pendapatan yang di dapatkan dari SHU bisa dikatakan kecil. Namun demikian, penghasilan pertahun ini dapat membantu sedikit pemenuhan kebutuhan rumah tangga anggota.

Pendapat ibu Nuningsih juga didukung oleh pemaparan ibu Astuti menjelaskan Bagaimana pelayanan Koperasi Pegawai Negeri (KPN) Kasabua Ade kepada anggotanya:

"Alhamdulilah dek, kalau saya butuh uang untuk keperluan pentin saya bisa langsung pinjam di koperasi, tidak butuh pengurusan yang lama dan berbelit-belit, gajinya memang sedikit dek tapi pelayananya ini sangat membantu saya."17

\section{Pembahasan}

Analisis Peran Koperasi Pegawai Negeri (KPN) Kasabua Ade dalam meningkatkan kesejahteraan ekonomi anggota.

Dari hasil penelitian mengenai Peran Koperasi Pegawai Negeri (KPN) Kasabua Ade dalam meningkatkan kesejahteraan ekonomi anggota. Pihak Koperasi sudah memikirkan sesuai dengan prinsip ekonomi. Ketika realisasi keuangan atau uang yang di cairkan ke anggotanya untuk dipergunakan dengan usaha mereka masing-masing. Pada saat mereka menjalankan sebuah roda bisnis dengan bantuan koperasi yang menyediakan modal kerja mereka secara langsung perekonomian dan kesejahteraan mereka terpenuhi.

Dalam meningkatkan kesejahteraan ekonomi anggota secara keseluruhan bukan hanya ekonominya yang di bantu, tapi semua, dari segala bentuk permasalahan kehidupan sosial, tidak hanya masalah ekonomi mereka. Koperasi

16 St rahmawati, Wawancara 29 Oktober 2021

17 Astuti, Wawancara 29 Oktober 2021 
hadir untuk membantu ketika ada anggota yang sudah terjerumus dalam sistem rentenir di daerahnya masing-masing, anggota siap membantu, membayarkan, menghentikan kegiatan bunga-berbunga tersebut, supaya anggota tidak makin terjerat.

Kesejahteraan itu sendiri merupakan suatu kondisi aman, damai, dan tenang. Dalam konteks penelitian ini, sejahtera yang di maksud yaitu suatu kondisi di mana anggota Koperasi Pegawai Negeri (KPN) Kasabua Ade dapat tercukupi kehidupan baik dari sisi material (pendapatan) maupun non material (kemampuan membeli barang). Badan pusat stastistik memiliki beberapa indikator yang di jadikan ukuran untuk melihat tingkat kesejahteraan rumah tangga. Al-Qur'an juga menjelaskan tentang bentuk dari kesejahteraan itu. Hal inilah yang menjadi ukuran dalam melihat peningkatan kesejahteraan yang dirasakan oleh anggota Koperasi Pegawai Negeri (KPN) Kasabua Ade, adapun indikator tersebut antara lain:

1. Pendapatan Material

Pendapatan merupakan jumlah uang yang diterimah atas suatu pekerjaan yang di lakukan. Pendapatan ini akan mempengaruhi bayaknya barang yang dikonsumsi. Artinya semakin tinggi pendapatan yang diterima oleh seseorang maka semakin tinggi pula tingkat konsumsi seseorang yang pada akhirnya taraf hidup seseorang akan berubah kearah yang lebih baik.

Anggota Koperasi mendapatkan pendapatan dari SHU yang diperoleh Koperasi Pegawai Negeri (KPN) Kasabua Ade, adapun anggota Koperasi, selain mendapatkan SHU juga mendapat pendapatan berupa gaji. SHU hingga pada akhir tahun Koperasi Pegawai Negeri (KPN) Kasabua Ade yaitu Rp 161,801,658, dan dibagikan kepada anggota sesuai dengan modal dan transaksi usaha yang dilakukan anggota itu sendiri.

Selain itu salah satu konstribusi Koperasi Pegawai Negeri (KPN) Kasabua Ade dalam meningkatkan kesejahteraan anggota di Koperasi Pegawai Negeri (KN) Kasabua Ade yang bersifat ekonomi. Berdasarkan hasil wawancaran dnegan ibu Nuningsih dapat disimpulkan bahwa Koperasi Pegawai Negeri (KPN) Kasabua Ade memberikan kemudahan kepada anggota dalam hal pemberian pinjaman, terutama terhadap suatu hal yang mendesak. Inilah yang menjadi salah satu tujuan koperasi, yang hadir mampu memberikan kemudahan kepada anggota yang pada akhirnya akan tercipta kesejahteraan bagi anggota. Pinjaman yang diberikan Koperasi kepada anggota maksimal Rp 5.000.000, pemberian pinjaman tidak serta merta diberikan secara langsung kepada anggota, tetapi harus melalui tahapan. Alasanya untuk menghindari pinjaman bermasalah yang disebabkan oleh ketidakmampuan anggota membayar. 
2. Kemampuan Anggota Membeli Barang (Non Materi)

Terpenuhinya kebutuhan konsumsi (hilangnya rasa lapar). Dalam ekonomi Islam terpenuhinya kebutuhan konsumsi merupakan salah satu indikator kesejahteraan, namun Islam memandang tidak boleh berlebihlebihan dalam konsumsi. Berdasarkan hasil wawancara dengan ibu St Rahmawati peneliti menyimpulkan bahwa Koperasi Pegawai Negeri (KPN) Kasabua Ade bagi anggota itu memberikan peranan, termasuk kepada anggota yang memperoleh SHU dari Koperasi. Anggota Koperasi Pegawai Negeri (KPN) Kasabua Ade, pada umumnya memiliki pekerjaan juga sehingga bergabung pada Koperasi ini membantu menambah pemasukan. Pendapatan yang di dapatkan dai SHU Koperasi Pegawai Negeri (KPN) Kasabua Ade bisa dikatakan kecil. Namun demikian, penghasilan pertahun ini dapat membantu sedikit pemenuhan kebutuhan rumah tangga anggota.

\section{KESIMPULAN}

Koperasi Pegawai Negeri (KPN) Kasabua Ade Kota Bima ini memiliki Peran yang sangat besar terhadap anggota dalam mensejahteraan ekonomi anggota. Peran Koperasi tersebut antara lain: membantu memberikan pinjaman kepada anggota yang membutuhkan tanpa syarat yag berbelit-belit, memberikan jaminan kesehatan, pendidikan dan SHU kepada anggota Koperasi Pegawai Negeri (KPN) Kasabua Ade.

\section{DAFTAR PUSTAKA}

Ahmad Usman, M. Si, “Mari Belajar Meneliti”, (Jakarta: Granata Press 2009)

Bernhard Limbang pengusaha koperasi (Jakarta selatan margaretha pustaka Jl. Agung Raya no. 10 Lenteng Agung)

Burhanuddin Koperasi syariah dan pengaturan Di Indonesia, Malang (UIN-Maliki Press 2012)

Dahliana Sukmasari "Konsep kesejahteraan masyarakat dalam pespektif Al Qur'an", jounal of Qur'an and Hadis Studies, Vol. 3 No. 1 (juni 2020)

Ismail, Kemiskinan Perspektif Ekonomi Islam, Jurnal Ekonomi Syariah (J-ESA), Volume 3, Nomor 1, 2020.

Jumriani Nur, Peran koperasi dalam meningkatkan kesejahteraan anggotanya pada koperasi Masjid Al- Markaz Al-Islam makasar (Skripsi “universitas Islam Negeri Alaudin Makassar 2019)

Sahril Akbar, Tinjauan Hukum Islam Mengenai Praktik Koperasi Kpn Kasabua Ade Kota Bima,("Skripsi" IAI Muhammadiyah Kota Bima,2020)

Sugiono, "Metode Penelitian Kuantitatif, Kualitatif dan RED", (Bandung: Alfabeta, $\mathrm{CV}, 2013)$. 
Triana Sofiani, “Konstruksi Norma Hukum Koperasi Syariah Dalam Kerangka Sistem Hukum Koperasi Nasional", Jurnal Hukum Islam, Vol. 12, No. 1, (Desember, 2014) 